\title{
Virulence of Lasiodiplodia theobromae the causal of grapevine die-back disease in Egypt
}

\author{
El-Shaery, S.A.*; G.M. El-Habbaa**; Abdou, M.M Mahdy**; F. G. Mohamed** and Mourad, M*. \\ * Plant Pathology Institute, Agri. Res. Center (ARC), Giza, Egypt. \\ ** Plant Pathology Dept., Fac. Agric., Benha Univ., Egypt
}

\begin{abstract}
Isolation trails from die-backed grapevine shoots during season 2011 confirmed that Lasiodiplodia theobromae was more frequently isolated fungus than others from symptomatic shoots collected from the five different vineyards in the surveyed governorates. Lasiodiplodia theobromae-B (Beheira isolate) recorded the highest frequent one while the lowest one was in Sharkia. Testing the five isolates of $L$. theobromae (B, G, M, $\mathrm{D}$, and $\mathrm{S}$ ) on wounded shoots (5 $\mathrm{mm}$ long, $2 \mathrm{~mm}$ deep at distance $30 \mathrm{~cm}$ down the terminal bud) using disk technique induced grapevine die-back symptoms while, the other isolated fungi i.e., Alternaria alternata, Aspergillus niger and Fusarium solani, were not able to induce die-back symptoms onto artificially inoculated grapevine shoots. Increasing the incubation period of inoculated grapevine shoots from 7-30 days increased gradually the averages of die-backed areas for all tested $L$. theobromae isolates with significant differences among them at all incubation periods. Also, all five isolates of $L$. theobromae (B, G, M, D, and S) were able to cause die-back symptoms onto grapevine shoots at all incubation periods using spore suspension technique. Also, $L$. theobromae-B isolate (Beheira isolate) was highest infective one causing die-back symptoms at 30 days post inoculation followed by L. theobromae-G and $\mathrm{M}$ isolates respectively. All tested cultivars i.e., Thompson seedless, Flame seedless, Crimson and Romi Ahmer were susceptible to infection with $L$. theobromae isolate-B, however, Thompson seedless cv. was the highly susceptible one to infection with dieback disease.
\end{abstract}

Key words: Lasiodiplodiatheobromae, isolation, pathogenicity, grapevine,

\section{Introduction}

Table grape (Vitis vinifera L.) is a wildly spread fruit crop which occupied the second most important fruit crop following citrus fruits. It is cultivated mainly for exportation, table use, fresh juice and raisin. Recently, grapes are widely cultivated in the newly reclaimed lands. Grapevine die-back is one of the most important diseases all over the world which attacked twigs of grapevine and cause great losses in the field. Lasiodiplodia theobromae (syn. Botrydiplodia theobromae, Diplodia natalensis) is the pycnidial state of Botryosphaeria rhodina, a pathogen that causes cankers and dieback in many woody and herbaceous species. Many investigators studied die-back disease of grape in Egypt (ElGoorani and El-Meleigi, 1972; Farag, 1998; Saber, 1998; Kamhawy, 2001; Abo Rehab et al., 2013 and Haggag, et al., 2013). El-Goorani and ElMeleigi (1972) reported, for the first time, that Lasiodiplodia theobromae (Pat.) Griff. \& Maubl. (as Botryodiplodia theobromae Pat.) is the causal pathogen of die-back on grapevine in Egypt. Arl and Oz (1990) in Turkia isolated L. theobromae from dead shoots with blight symptoms on young grapevine. Kotze et al. (2011) reported that trunk diseases of grapevine are caused by numerous pathogens, including Eutypa lata, Phaeomoniella chlamydospora, and species of Botryosphaeriaceae (incl. Botryosphaeria and aggregate genera), Phomopsis and Phaeoacremonium. Mondello et al. (2013) reported grapevine decline caused by
Lasiodiplodia theobromae for the first time in Sicily, Italy.Rodríguez-Gálvez et al. (2015) identified and tested pathogenicity of Lasiodiplodia theobromae for the first time as causal agent of die-back of table grapes in Peru. Correia et al. (2016) isolated and identified eight species of Lasiodiplodia as $L$. brasiliense, L. crassispora, $L$. egyptiacae, $L$. euphorbicola, L. hormozganensis, L. jatrophicola, L. pseudotheobromae and $L$. theobromae from Botryosphaeria die-back of table grape in the Sao Francisco Valley, the main Brazilian exporting region using phylogenetic analysis based on partial sequences of translation elongation factor 1-a (EF1a) and internal transcribed spacer (ITS) sequences, in combination with morphometric characteristics of conidia. They also evaluated their pathogenicity and virulence in green shoots of table grape.

As for reaction of some grapevine cultivars to die-back infection, Radwan (1985) suggested that, berries of cv. Romi Red was the highest susceptible one to infection by B.theobromae, while cv. Gharibi was less susceptible. The cultivars Azazi Bez-ElAnz; Fayoumi and Banati showed a moderate infection. Farag (1998) found that, Bez El-Anz cultivar was high susceptible to infection with $B$. theobromae while, Robi king was less susceptible. Saber (1998) indicated that all the tested cultivars are susceptible to infection with Phomopsisviticola. Thompson seedless and Moscat of Alexandria cultivars showed the highest infection while cvs. Fayoumi and Moscat black were moderately infected. While, the cvs. Romi Red, Gharibi and 
Hadidy exhibited the lowest infection. Kamhawy (2001) evaluated the susceptibility of six grapevine cultivars, i.e. Thompson seedless, Flame seedless, King Robi, RomiAhmir, and Bez El-Anz to infection with $L$. theobromae. He found that all the tested grapevine cultivars were susceptible to infection with L. theobromae, the causal fungus of die-back in two successive growing seasons.

This study aimed to isolate and testing the pathogenicity of grapevine die-back disease. Also, studying the reaction of some grapevine cultivars to infection with die-back disease.

\section{Materials and Methods}

\section{Isolation, purification and identification of the causal organism(s):}

Grapevine twigs showing die-back disease symptoms were collected from five localities belonging to five governoratesi.e.,Beheira (Noubaria), Gharbiya (El-Santa), Dakahliya (Aga), Sharkiya (Belbase), Minia (Samalot) during season 2011. The inspected grapevine cultivars are Thompson seedless, Flame seedless, Crimson, Romi Ahmer. Sampls were brought to the laboratory of Fruit and Woody Trees Diseases Department, Plant Pathology Research Institute, Agricultural Research Center, Giza. Samples were washed thoroughly with tap water, then cut to small portions $(0.5 \mathrm{~cm})$, sterilized by dipping in $0.1 \%$ sodium hypochlorite for 3 minutes, washed again by rinsing several times in sterilized distilled water and then they were dried between two pieces of sterilized filter paper (Watman No. 1). The sterilized portions were placed in Petri dishes containing $10-15 \mathrm{~mL}$ of Potato Dextrose Agar medium (PDA).The inoculated Petri plates were incubated at $25^{\circ} \mathrm{C}$ for seven days. Hyphal tip (Brown, 1924) and single spore (Zhang et al., 2013) techniques were used to purify the associated organisms on PDA slants.All appeared fungal colonies were picked and transferred to previously prepared PDA plates. These fungal isolates were examined morphologically and microscopically and then they were identified according to their cultural characteristics at Plant Pathology Department, Faculty of Agriculture, Benha University. Identification was confirmed at Mycology and Plant Diseases Survey, Plant Pathology Research Institute, Agric. Res. Center, (ARC) using the description of Punithalingam (1976)and BarnettandHunter (2006).Stock cultures were maintained on PDA slants and kept in a refrigerator at $5-10^{\circ} \mathrm{C}$ and routinely sub-cultured on fresh slants every three months.

\section{Pathogenicity tests:}

The isolated fungi were tested for their pathogenic abilities using three techniques of inoculation. The first one, superficial wounds $(5 \mathrm{~mm}$ long, $2 \mathrm{~mm}$ deep at distance $30 \mathrm{~cm}$ down the terminal bud) were made on recent grapevine shoots (about 1 meter long) of one year old grapevine plants (cv. Thompson seedless). The tested fungal isolates were inoculated ( $5 \mathrm{~mm} \varnothing$ inoculum disc, 7 days-old) onto the wounded shoots. Then, the inoculated shoots with each one of the tested fungi were tightly covered with plastic parafilm at the site of wound. The second technique, woody toothpicks were autoclaved for sterilizing, then transferred to the prepared PDA plates prior to inoculation with an equal disc $(5 \mathrm{~mm}$ $\varnothing)$ of each one of the tested fungi for each particular PDA plate then left to grow for one week at $25^{\circ} \mathrm{C}$. Tips of the prepared woody toothpicks having inoculants were immersed into grapevine shoots at the same previously distance down the terminal bud as mentioned above. The inoculated shoots were covered with plastic bags to maintain the relative humidity around inoculation site of each one of the tested fungi to allow the fungal isolates to grow well for $48 \mathrm{hrs}$ before removing them. The third inoculation technique, $0.1 \mathrm{~mL}(=100 \mu \mathrm{L})$ of the prepared spore suspension of each one of the tested fungal isolates $\left(1 \times 10^{6}\right)$ (La Prade and Manwiller, 1977) were added to the wounded shoots $(1 \mathrm{~cm}$ longitudinal wound with the aid of scalable) at the same distance down the terminal bud. The inoculated shoots were covered with plastic bags as mentioned above. Three shoots were used as replicates for each particular treatment with the three inoculation techniques. Control treatments were wounded shoots inoculated with discs of PDA medium without any one of the tested fungi, inoculated shoots with sterilized woody toothpicks free of inoculants and wounded shoots inoculated with sterilized distilled water at the site of wound. Data were recorded as long $(\mathrm{mm})$ of die-backed area at 7, 14, 21 and 30 days post inoculation of each one of the tested fungi according to Bender (1941).

\section{Reaction of some grapevine cultivars to die- dieback infection:}

In this trail, four different grapevine cultivars, i.e. Thompson seedless, Flame seedless, Crimson and RomiAhmer were tested for their reaction to die-back infection caused by Lasiodiplodia (Botryodiplodia) theobromae-B (Beheira isolate, the more virulent one among other tested isolates). In this respect, grapevine nurslings (one year old) of each one of the tested grapevine cultivars were individually inoculated with tested pathogen (Lasiodiplodia (Botryodiplodia) theobromae-B) using the woody toothpicks technique as mentioned above in pathogenicity test. Five nurslings were used for each particular treatment of the four tested cultivars. Also, five nurslings inoculated with sterilized woody toothpicks free of the inoculant served as control. All nurslings were kept under greenhouse conditions and watered as needed. Data were recorded as long ( $\mathrm{mm})$ of die-backed area at 7, 14, 21 and 30 days post 
inoculation with the tested fungus according to Bender (1941).

\section{Statistical analysis:}

The experiment was arranged in a randomized complete blocks design and the obtained data were subjected to analysis of variance and significant differences among means according to Snedecor and Cochran (1980). In addition significant differences among means were distinguished according to the Duncan multiple test range Duncan (1955).

\section{Results and Discussion}

\section{Isolation and identification of the causal $\operatorname{organism}(\mathbf{s})$ :}

Data in Table 1 reveal that the isolated fungi from die-backed grapevine shoots during season 2011 were identified as L. theobromae, Fusarium solani, Alternaria alternata, Aspergillus niger, Rhizopus nigricans which belonging to five different genera and species. Lasiodiplodia theobromae fungus was more frequently isolated than others from symptomatic shoots collected from the five different vineyards in the surveyed governorates. In this respect, the highest frequency No. and \% of Lasiodiplodia theobromae isolates were recorded in Beheira and Gharbiya governorates respectively while, the lowest frequency No. and $\%$ of the fungus were recorded in Sharkiya. The other isolated fungi i.e., Fusarium solani, Alternaria alternata, Aspergillus niger, Rhizopus nigricans were recorded in the five inspected locations with low frequency No. and \% with also some exceptions where, Aspergillus niger was not isolated from samples of Dakahliya governorate and Rhizopus nigricans was not detected in samples of Beheira, Gharbiya and Menia governorates. Rhizopus nigricans recorded the least frequency No. and \% among all fungal isolates in the five inspected governorates. These results are in accordance with those reported by El-Goorani and El-Meleigi (1972) who reported for the first time, that Lasiodiplodia theobromae (Pat.) Griff. \&Maubl (Botryodiplodia theobromae Pat.) is the causal pathogen of dieback on grapevine in Egypt. In Italy, Mondello et al. (2013) reported that grapevine decline caused by Lasiodiplodia theobromae was reported for the first time in Sicily, vines showing similar declining symptoms have been also found in other grape-growing areas of western and central Sicily. We report the result of a study on fungi associated with grapevine decline in Sicily, with particular regard to those belonging to the Botryosphaeriaceae. Four species were found to be associated with declined vines, namely Diplodia seriata, Lasiodiplodia sp., Neofusicoccum parvum and Neofusicoccum vitifusiforme, the latter species reported for the first time on Vitisvinifera.

Table 1. Frequency No. and frequency $\%$ of isolated fungi from die-backed grapevine shoots during season 2011.

\begin{tabular}{lcccccccccc}
\hline Governorate & \multicolumn{3}{c}{ Beheira } & \multicolumn{2}{c}{ Gharbiya } & \multicolumn{2}{c}{ Dakahliya } & \multicolumn{2}{c}{ Sharkiya } & \multicolumn{2}{c}{ Menia } \\
\hline & Freq. & Freq. & Freq. & Freq. & Freq. & Freq. & Freq. & Freq. & Freq. & Freq. \\
Isolated fungi & No & $\%$ & No & $\%$ & No & $\%$ & No & $\%$ & No & $\%$ \\
\hline Lasiodiplodiatheobromae & $30 \mathrm{a}$ & $75.0 \mathrm{a}$ & $24 \mathrm{a}$ & $60.0 \mathrm{a}$ & $16 \mathrm{a}$ & $40.0 \mathrm{a}$ & $13 \mathrm{a}$ & $32.5 \mathrm{a}$ & $19 \mathrm{a}$ & $47.0 \mathrm{a}$ \\
Fusariumsolani & $5 \mathrm{~b}$ & $12.5 \mathrm{~b}$ & $8 \mathrm{~b}$ & $20.0 \mathrm{~b}$ & $12 \mathrm{~b}$ & $30.0 \mathrm{~b}$ & $10 \mathrm{~b}$ & $25.0 \mathrm{~b}$ & $10 \mathrm{~b}$ & $25.0 \mathrm{~b}$ \\
Alternariaalternata & $3 \mathrm{c}$ & $7.5 \mathrm{c}$ & $5 \mathrm{c}$ & $12.5 \mathrm{c}$ & $9 \mathrm{c}$ & $22.5 \mathrm{c}$ & $8 \mathrm{c}$ & $20.0 \mathrm{c}$ & $7 \mathrm{c}$ & $17.5 \mathrm{c}$ \\
Aspergillusniger & $2 \mathrm{c}$ & $5.0 \mathrm{~d}$ & $3 \mathrm{c}$ & $7.5 \mathrm{~d}$ & $0 \mathrm{e}$ & $0.0 \mathrm{e}$ & $6 \mathrm{~d}$ & $15.0 \mathrm{~d}$ & $4 \mathrm{~d}$ & $10.0 \mathrm{~d}$ \\
Rhizopusnigericans & $0 \mathrm{~d}$ & $0.0 \mathrm{e}$ & $0 \mathrm{~d}$ & $0.0 \mathrm{e}$ & $3 \mathrm{~d}$ & $7.5 \mathrm{~d}$ & $4 \mathrm{e}$ & $7.5 \mathrm{e}$ & $0 \mathrm{e}$ & $0.0 \mathrm{e}$ \\
\hline Total & 40 & 100 & 40 & 100 & 40 & 100 & 41 & 100 & 40 & 100 \\
\hline Means within a column having the same letters are not significantly different according to Duncan's Multiple Range Testat 5\% level.
\end{tabular}

\section{Pathogenicity tests:}

\subsection{Pathogenicity of isolated fungi using disk} technique:

In this trail, wounded shoots $(5 \mathrm{~mm}$ long, $2 \mathrm{~mm}$ deep at distance $30 \mathrm{~cm}$ down the terminal bud) of one year old grapevine plants (cv. Thompson seedless) were used. Discs $(\varnothing 0.5 \mathrm{~cm})$ of each one of the tested fungi taken from 7 days-old cultures were put individually on the wounded sites before covering them tightly with plastic parafilm till appearance of die-back symptoms at the different incubation days. Data in Table 2ashow that all five tested isolates of L. theobromae (B, G, M, D, and S) using disk technique were able to induce grapevine die-back symptoms, while, A. alternata, Aspergillus niger and Fusarium solani, were not able to induce die-back symptoms onto artificially inoculated grapevine shoots. Also, results indicate that $L$. theobromae(B-isolate)was the highest pathogenic isolate among the others tested $L$. theobromaeisolates where it caused the highest average of die-backed area at 30 days post inoculation followed by $L$. theobromae $(\mathrm{G} \& \mathrm{M})$ isolates. It is clear also from the obtained results that increasing the incubation period on inoculated grapevine shoots from 7-30 days increased gradually the averages of die-backed areas for all tested $L$. theobromae isolates with significant differences among them at all incubation periods. 
Table 2a. Pathogenicity of isolated fungi using disk technique.

\begin{tabular}{|c|c|c|c|c|c|}
\hline \multirow{2}{*}{ Fungal isolates } & \multicolumn{5}{|c|}{ Average of necrotic length $(\mathrm{mm})$ after day } \\
\hline & 7 days & 14 days & 21 days & 30 days & Mean \\
\hline Lasiodiplodiatheobromae $(B) *$ & $9.0 \mathrm{kl}$ & $12.16 \mathrm{~h}$ & $22.66 \mathrm{e}$ & $72.00 \mathrm{a}$ & 28.95 \\
\hline Lasiodiplodiatheobromae $(G)^{*}$ & $8.51 \mathrm{~m}$ & 11.90hi & $21.00 f$ & $71.00 \mathrm{ab}$ & 28.10 \\
\hline Lasiodiplodiatheobromae $(M) *$ & $8.01 \mathrm{~m}$ & 11.50hi & $20.50 f$ & $70.00 \mathrm{~b}$ & 27.50 \\
\hline Lasiodiplodiatheobromae $(D) *$ & $7.51 \mathrm{~m}$ & $10.50 \mathrm{ij}$ & $20.00 f$ & $68.00 \mathrm{c}$ & 26.50 \\
\hline Lasiodiplodiatheobromae $(S) *$ & $7.0 \mathrm{~m}$ & $10.00 \mathrm{jk}$ & $18.50 \mathrm{~g}$ & $65.00 \mathrm{~d}$ & 25.13 \\
\hline Fusariumsolani & - & - & - & - & - \\
\hline Alternariaalternata & - & - & - & - & - \\
\hline Aspergillusniger & - & - & - & - & - \\
\hline Control & - & - & - & - & \\
\hline Mean & 8.00 & 11.21 & 20.53 & 69.20 & \\
\hline
\end{tabular}

Means within a column having the same letters are not significantly different according to Duncan's Multiple Range Testat 5\% level. * B: Beheira. * G: Gharbiya. * M: Menia * D: Dakahliya * S: Sharkiya

\subsection{Pathogenicity of isolated fungi using toothpick technique.}

Data in Table $\mathbf{2 b}$ show that all tested five isolates of L. theobromae (B, G, M, D, and S) were able to cause die-back symptoms onto grapevine shoots at all incubation periods using toothpick technique. On the other hand, the rest of tested fungi were not able to incite any die-back symptoms at all incubation periods. It is clear also from data that increasing the incubation period from 7-30 days led to increasing the die-back symptoms on inoculated grapevine shoots where the highest die-backedarea was recorded at 30 days post inoculation. Also, $L$. theobromae-B isolate was highest infective isolate causing die-back symptoms at 30 days post inoculation followed by $L$. theobromae-G\&M isolates respectively.

\subsection{Pathogenicity of isolated fungi using spore suspension technique.}

As clear in Table 2c only the five isolates of $L$. theobromae (B, G, M, D, and S) were able to cause die-back symptoms onto grapevine shoots at all incubation periods using spore suspension technique. Meanwhile, the other tested isolates were not able to cause any die-back symptoms when tested for their pathogenic abilities at the same conditions. Also, increasing the incubation periods from 7-30 days post inoculation with $L$. theobromae $(\mathrm{B}, \mathrm{G}, \mathrm{M}, \mathrm{D}$, and $\mathrm{S}$ ) isolates led to increasing gradually the dieback infection to reach its maximum at 30 days post inoculation. Moreover, L. theobromae-B isolate was the highest infective one comparing with the other tested $L$. theobromae isolates with clear significance among them. The isolates $L$. theobromae-G\&M came in the second rank while $L$. theobromae-S was least pathogenic isolate among the others. All obtained results of pathogenicity with the different inoculation techniques could be interpreting in light the findings of Mohammadi et al. (2014) who worked on2-yearold potted cypress plants and green shoots of grapevine. They found that Neofusicoccum parvum was more virulent than the other tested species and caused the largest lesions on both hosts.

Table 2b. Pathogenicity of isolated fungi using toothpick technique.

\begin{tabular}{|c|c|c|c|c|c|}
\hline \multirow{2}{*}{ Fungal isolates } & \multicolumn{5}{|c|}{ Average of necrotic length $(\mathrm{mm})$ after day } \\
\hline & 7 days & 14 days & 21 days & 30 days & Mean \\
\hline Lasiodiplodiatheobromae $(B) *$ & $6.00 \mathrm{i}-1$ & 7.10hi & $9.50 \mathrm{f}$ & $34.66 \mathrm{a}$ & 14.31 \\
\hline Lasiodiplodiatheobromae $(G) *$ & $5.88 \mathrm{j}-1$ & $6.50 \mathrm{~h}-\mathrm{k}$ & $8.20 \mathrm{~g}$ & $30.10 b$ & 12.67 \\
\hline Lasiodiplodiatheobromae $(M) *$ & 5.101 & $6.50 \mathrm{~h}-\mathrm{k}$ & $7.20 \mathrm{gh}$ & $29.00 \mathrm{c}$ & 11.95 \\
\hline Lasiodiplodiatheobromae $(D) *$ & 5.001 & $6.00 \mathrm{i}-1$ & $7.00 \mathrm{~h}-\mathrm{j}$ & $27.00 \mathrm{~d}$ & 11.25 \\
\hline Lasiodiplodiatheobromae $(S) *$ & 5.001 & $5.50 \mathrm{kl}$ & $6.00 \mathrm{i}-1$ & $25.00 \mathrm{e}$ & 10.38 \\
\hline Fusariumsolani & - & - & - & - & -- \\
\hline Alternariaalterndta & - & - & - & - & -- \\
\hline Aspergillusniger & - & - & - & - & -- \\
\hline Control & - & - & - & - & -- \\
\hline Mean & 5.40 & 6.32 & 7.58 & 29.15 & \\
\hline
\end{tabular}


Table 2c. Pathogenicity of isolated fungi using spores suspension technique.

\begin{tabular}{|c|c|c|c|c|c|}
\hline \multirow{2}{*}{ Fungal isolates } & \multicolumn{5}{|c|}{ Average of necrotic length $(\mathrm{mm})$ after day } \\
\hline & 7 days & 14 days & 21 days & 30 days & Mean \\
\hline Lasiodiplodiatheobromae $(B) *$ & $5.50 \mathrm{ij}$ & $7.00 \mathrm{gh}$ & $8.50 \mathrm{e}$ & $18.33 \mathrm{a}$ & 9.83 \\
\hline Lasiodiplodiatheobromae $(G) *$ & $5.20 \mathrm{j}$ & $6.50 \mathrm{~h}$ & $8.00 \mathrm{ef}$ & $17.00 \mathrm{~b}$ & 9.18 \\
\hline Lasiodiplodiatheobromae $(M) *$ & $5.00 \mathrm{j}$ & $6.20 \mathrm{hi}$ & $7.50 f g$ & $16.00 \mathrm{c}$ & 8.68 \\
\hline Lasiodiplodiatheobromae $(\mathrm{D}) *$ & $5.00 \mathrm{j}$ & $6.40 \mathrm{~h}$ & $7.00 \mathrm{gh}$ & $15.40 \mathrm{~cd}$ & 8.45 \\
\hline Lasiodiplodiatheobromae $(S) *$ & $5.00 \mathrm{j}$ & $5.50 \mathrm{ij}$ & $6.50 \mathrm{~h}$ & $14.70 \mathrm{~d}$ & 7.93 \\
\hline Fusariumsolani & - & - & - & - & \\
\hline Alternariaalterndta & - & - & - & - & \\
\hline Aspergillusniger & - & - & - & - & \\
\hline Control & - & - & - & - & \\
\hline Mean & 5.14 & 6.32 & 7.50 & 16.29 & \\
\hline
\end{tabular}

3. Reaction of some grapevine cultivars to dieback:

In this trail, four different grapevine cultivars, i.e. Thompson seedless, Flame seedless, Crimson and Romi Ahmer were evaluated for their susceptibility to die-back infection caused by L. theobromae-B (the highly pathogenic isolate among the others tested). In this respect, shoots of grapevine nurslings (one year old) were individually inoculated with $L$. theobromae-B isolates using the toothpick technique as mentioned previously. Data in Table 3 show that, all tested cultivars i.e., Thompson seedless, Flame seedless, Crimson and Romi Ahmer were susceptible to infection with $L$. theobromae isolate-B. Also, Thompson seedless $\mathrm{cv}$. was the highly susceptible cultivar to infection with dieback disease where the highest average of die-backed area was recorded on its shoots at 30 days post inoculation followed by the cvs. Crimson and Flame seedless respectively. Meanwhile, Romi Ahmer was the less susceptible one to die-back infection. Data cleared also that increasing the incubation period from 7-30 days post inoculation of the tested cultivars affected positively the die-back incidence. In this respect, similar results were obtained by Kamhawy (2001) who evaluated the susceptibility of six grapevine cultivars, i.e. Thompson seedless, Flame seedless, King Robi, Romi Ahmir, and Bez El-Anz to infection with $L$. theobromae. He found that all the tested grapevine cultivars were susceptible to infection with $L$. theobromae, the causal of dieback in the two successive growing seasons.

Table 3. Reaction of some grapevine cultivars to die-dieback infection

\begin{tabular}{lccccc}
\hline \multirow{2}{*}{ Cultivars } & \multicolumn{5}{c}{ Average of necrotic length $(\mathbf{m m})$ after day } \\
\cline { 2 - 6 } & $\mathbf{7 ~ d a y s}$ & $\mathbf{1 4}$ days & 21 days & 30 days & Mean \\
\hline Thompson seedless & $8.00 \mathrm{ij}$ & $12.16 \mathrm{gh}$ & $25.33 \mathrm{e}$ & $91.66 \mathrm{a}$ & 34.29 \\
Flame seedless & $6.50 \mathrm{j}$ & $8.00 \mathrm{ij}$ & $19.16 \mathrm{f}$ & $75.00 \mathrm{c}$ & 27.17 \\
Crimson & $7.16 \mathrm{ij}$ & $9.66 \mathrm{hi}$ & $22.83 \mathrm{e}$ & $85.00 \mathrm{~b}$ & 31.16 \\
Romi Ahmer & $6.00 \mathrm{j}$ & $7.33 \mathrm{ij}$ & $14.83 \mathrm{~g}$ & $55.00 \mathrm{~d}$ & 20.79 \\
Mean & 6.92 & 9.29 & 20.54 & 76.67 & \\
\hline
\end{tabular}

Means within a column having the same letters are not significantly different according to Duncan's Multiple Range Test at 5\% level.

\section{References}

Abo Rehab, M.E.A.;Korra, A.K.M., Kamhawy, M.A.M. and Youssef,K.Y.A (2013). Fungal species associated with graft union on grapevine, its impact on graft failure process and attempted solutions in Egypt, International Journal of Agriculture and Forestry, 3(2): 5259.

Arl, M. and OZ, S. (1990). New record: A new fungus disease on vine in Turkey. Journal of Turkish Phytopathology, 19 (2): 99-101 (c.f. Rev. PI Path., 71, (7): 3579.

Barnett, H.L. and Hunter,B.B. (2006). Illustrated Genera of Imperfect Fungi. $4^{\text {th }}$ Edn., American Phytopathological Society (APS Press), St. Paul, Minnesota, Pages: 217.
Bender, T.R. (1941). Fusarium die-back of American holly. Plant Dis. Report., 25: 403.

Brown, W. (1924). Tow mycelial methods. A method of isolating single strains of fungi by cutting out a hyphal tip. Ann-Bot.,28:402-404.

Correia, K.C.; Silva, M.A.; de MoraisJr, M.A.; Armengol, J.; Phillips, A.J.L.; Camara, M.P.S. and Michereff, S.J. (2016). Phylogeny, distribution and pathogenicity of Lasiodiplodia species associated with dieback of table grape in the main Brazilian exporting region.Plant Pathology, 65: 92-103.

Duncan, D.B. (1955). Multiple range and multiple F test. Biometrices, 11:1- 24.

El-Goorani, M.A. and El-Meleigi, M.A. (1972). Die-back of grapevine by Botryodiplodia 
theobromae pat. In Egypt. Phytopathol. Mediterr., 11: 210- 211.

Farag, I.M. (1998). Studies on dieback disease of grape trees. M.Sc. Thesis, Fac. Agric., Cairo Univ. $101 \mathrm{p}$

Haggag, W.M.; Saleh, M. A. E.;Mostafa, I, and Adel, N. (2013). Mass production, fermentation, formulation of Pseudomonas putida for controlling of die-back and Phomopsis diseases on grapevine. Advances in Bioscience and Biotechnology, 4: 741-750.

Kamhawy, M.A. (2001). Studies on die-back disease of grapevine in A.R.E. Ph.D. Thesis Fac. Agric. Zagazig Univ., 219pp.

Kotze C.;Van Niekerk, J.;Mostert, L.;Halleen, F. and Fourie P. (2011). Evaluation of biocontrol agents for grapevine pruning wound protection against trunk pathogen infection. PhytopathologiaMediterranea50, S247-S263.

La Prade, J.C. and Manwiller, A. (1977). Relation of insect damage, vector, and hybrid reaction to aflatoxin B, recovery from field corn. Phytopathology,67:544-547.

Mohammadi, H.; Kazemi, S. and Farahmand, H. (2014).Phaeoacremonium and Botryosphaeriaceae species associated with cypress (Cupressussempervirens L.) decline in Kerman province (Iran). PhytopathologiaMediterranea, 53(1): 27-39.
Mondello, V.; Lo Piccolo, S.;Conigliaro, G.; Alfonzo, A.;Torta, L. and Burruano, S. (2013). First report of Neofusiccoccumvitifusiforme and presence of other Botryosphaeriaceae species associated with Botryosphaeria dieback of grapevine in Sicily (Italy). PhytopathologiaMediterranea, 52(2): 388-396.

Punithalingam, E. (1976).Botryodiplodia theobromae. CMI descriptions of pathogenic fungi and bacteria,519:1-2

Radwan (Fatma), M. (1985). Studies on grapevine fruit rot in A.R.E. M. Sc. Thesis. Fac. Agric. Cairo Univ., Egypt.

Rodríguez-Gálvez, E.; Maldonado, E. andAlves,A. (2015). Identification and pathogenicity of Lasiodiplodia theobromae causing die-back of table grapes in Peru. Eur. J. Plant Pathol.,141:477-489

Saber, M.M. (1998). Pathological studies on deadarm disease of grape in Egypt. Bull. Fac. Agric., Cairo Univ., 49:257-272.

Snedecor, G.W. and Cochran, W.G. (1980). Statistical methods. $7^{\text {th }}$ Edition. Iowa State Univ. Press, Ames. Iowa, U.S.A.

Zhang, K.; Su, Y.Y. and Cai, L. (2013). An optimized protocol of single spore isolation for fungi. Cryptogamie, Mycologie34(4):349-356.

$$
\begin{aligned}
& \text { القدرة المرضية لفطر لازيوديبلوديا ثيويرومي المسبب لمرض موت الأطارف علي العنب في مصر } \\
& \text { سامح عبد الوهاب الثعيري** ، جهاد محمد الهباء*** ، عبده مهدي محمد مهدي** ، فتحي جاد محمد**" ، مدحت يوسف مراد * }
\end{aligned}
$$

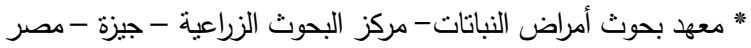

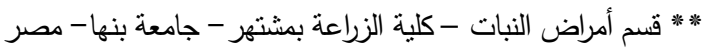

أكدت تجارب العزل من فروع العنب المصابة بمرض موت الأطارف خلا الموسم 2011 أن الفطر لازيوديبلوديا ثيوبرومي كان الأكثر

نكرارا بين الفطريات الأخري المعزولة من عينات الفروع المصابة بمرض موت الأطارف والمجمعة من حقول العنب في 5 محافظات مختلفة. كانت عزلة لازيونيلوديا ثيوبرومي المعزولة من عبنات العنب بمحافظة البحيرة هي الأكثر تكرارا بينما كانت عزلة الثرقية هي الأقل نكرارا. أدي إختبار 5 عزلات من فطر لازيوديبلوديا ثيوبرومي (B, G, M, D, and S) علي فروع عنب مجروحة ( طول الجرح 5 مم ، عمق الجرح 2 مم وييعد الجرح مسافة 30 سم أسفل البرعم الطرفي) باستخدام طريقة تلقيح الجرح بقرص من النمو الفطري الي إحداث أعراض موت التئ الأطارف علي العنب، بينما

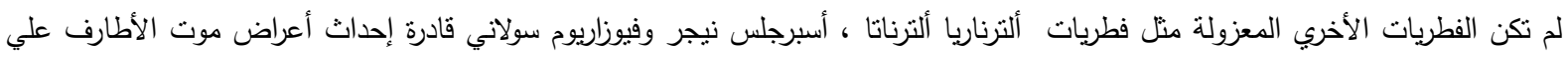

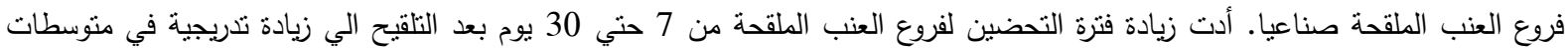
المناطق المصابة بموت الأطارف مع كل عزلات لازيوديبلوديا ثيوبرومي المختبرة مع وجود إختلافات معنوية بينهم عند كل فترات التحضين. كانت أيضا كل عزلات فطر لازيوديبلوديا ثيوبرومي (B, G, M, D, and S) قادرة علي أن تسبب أعراض موت الأطارف علي فروع العنب عند كل

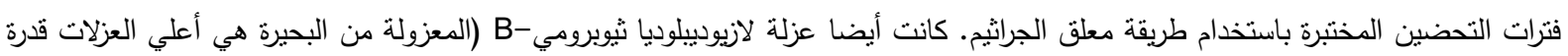

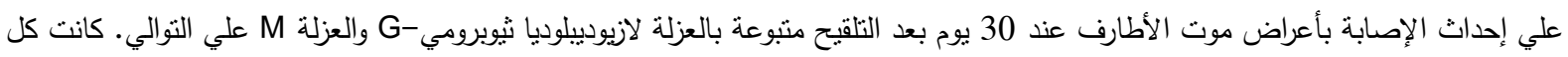

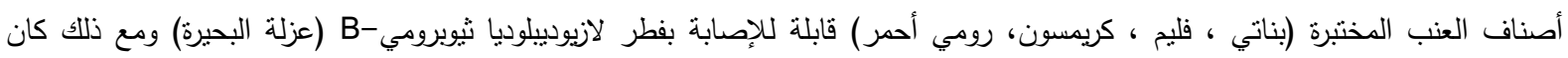
الصنف بناتي هو الأعلي قابلية للإصابة بمرض موت الأطارف بين باقي الأصناف المختبرة. 